DOI 10.37882/2223-2982.2022.01.38

\title{
НЕКОТОРЫЕ ТЕОРЕТИЧЕСКИЕ ОСОБЕННОСТИ РАЗВИТИЯ ИНОЯЗЫЧНОЙ КОММУНИКАТИВНОЙ КОМПЕТЕНТНОСТИ СТУДЕНТОВ В ВУЗЕ
}

\section{SOME THEORETICAL FEATURES OF THE DEVELOPMENT OF FOREIGN LANGUAGE COMMUNICATIVE COMPETENCE OF STUDENTS AT THE UNIVERSITY}

\section{O. Chudnova \\ R. Chvalun \\ N. Kizilova}

Summary: One of the tasks that modern Russian society poses to higher professional education is the training of highly qualified specialists and, consequently, the requirements for improving the quality of professional training are increasing, and in particular teaching oral foreign language communication, during which the formation and development of students' communicative competence takes place. Consideration of theoretical aspects contributes to a deeper and more detailed study of the problem of the formation of foreign language competence of students in the process of studying at the university.

Keywords: theoretical aspects, oral foreign language communication, communicative competence, professional competence of a specialist, organization of professional education, speech act, language as a means of expression.
$\Phi$ ормирование мультикультурной языковой личности будущего специалиста является одной из главнейших задач в процессе инновационного развития системы иноязычного образования. С быстрым развитием технологий и экономики, которое произошло в конце 19-го и начале 20-го века, для расширения международного общения, возросла потребность в людях с хорошим знанием иностранного языка. После Первой мировой войны функция языка выделяется при занятии иностранным языком как средство международного выражения, и через применение метода подражания учителю наблюдается развитие чувства языка у обучающегося. Изучение иностранного языка стало необходимым в различных сферах жизни и работы многих людей, которые путешествуют за границу, а также которые хотят общаться устно или письменно на иностранном языке. Не только растущая мобильность людей, но и развитие средств массовой информации также увеличило потребность в знание иностранного языка. Что мы понимаем под коммуникацией? Во - первых, это акт взаимодействия, прямой обмен между двумя или более
Чуднова Ольга Алексеевна

К.nсх.н., Ставропольский государственный аграрный университет

chudnova08@mail.ru

Чвалун Роза Владимировна

К.филол.н., Ставропольский государственный аграрный университет

chvalun_roza@mail.ru

Кизилова Наталья Игоревна

К.филол.н., Ставропольский государственный аграрный университет

natali0403_87@mail.ru

Аннотация: Одной из задач, которые ставит современное российское общество перед высшим образованием, является подготовка высококлассных специалистов, а, следовательно, возрастают требования к повышению качества профессиональной подготовки, и в частности обучению устному иноязычному общения, в процессе которого происходит формирование и развитие коммуникативной компетентности студентов. Рассмотрение теоретических аспектов способствует более глубокому и детальному изучению проблемы формирования иноязычной компетентности студентов в процессе обучения в вузе.

Ключевые слова: теоретические аспекты, устное иноязычное общение, коммуникативная компетентность, профессиональная компетентность специалиста, организация профессионального образования, речевой акт, язык, как средство выражения.

партнерами по коммуникации в устной или письменной формах, во- вторых, это средство передачи или получения информации от других и развитие связей между социальными действиями; возникающими как в частной сфере, так и на работе; Мобильность современных людей способствует приобретению таких навыков иностранного языка, с которыми каждый, будучи туристом или бизнесменом, мог бы общаться и быть понятым людьми за границей. Коммуникативные потребности также включают: понимание телевизионных программ, радиопрограмм, статей в прессе, книг, писем и т.п. Прежде всего, человек изучает иностранный язык, чтобы использовать его в целях общения в повседневных ситуациях, но владение иностранным языком также актуально сегодня и не менее важно делового общения. Итак, межличностная коммуникация немыслима без соответствующих языковых навыков. Примерная программа по дисциплине «Иностранный язык» для неязыковых вузов и факультетов, составленная в 2009 году под руководством С.Г. Тер-Минасовой определяет важнейшие стратегические особенности преподавания данной дисци- 
плины [Тер-Минасова, 2009]. Этот документ определяет не только примерный почасовой объем преподавания дисциплины «Иностранный язык», принципы ее преподавания, структуру программы, но и цели преподавания иностранного языка в неязыковом вузе. Основной целью преподавания языка для неязыковых направлений подготовки является «повышение исходного уровня владения иностранным языком, достигнутого на предыдущей ступени образования, и овладение студентами необходимым и достаточным уровнем коммуникативной компетенции для решения социально-коммуникативных задач в различных областях бытовой, культурной, профессиональной и научной деятельности при общении с зарубежными партнерами, а также для дальнейшего самообразования» [там же, 5]. Учитывая специфику преподавания иностранного языка на неязыковых факультетах вузов в кротчайшие сроки научить студентов пользоваться иностранным языком как средством межкультурного общения - целесообразно при составлении рабочих программ и написании учебных пособий, применять теорию и практику профессионально-ориентированного обучения, включающего использование таких интенсивных методов обучения, как метод проектов (Е.С. Полат, Е.И. Пассов), метод активизации возможностей личности и коллектива (Г.А. Китайгородская), метод профессионально-ориентированных учебных ролевых игр (О.А. Артемьева). Данный процесс предусматривает не только обучение иностранному языку как средству общения и передачи студентам социально и профессионально значимой информации, но формирование коммуникативно-проектировочных умений, под которыми понимается способность мотивированно, осознанно и самостоятельно осуществлять проектную деятельность на иностранном языке,

Как известно, модель общения является необычной, многогранной деятельностью, которая сопряжена с другими видами деятельности и связывает общение с другими явлениями. С помощью языка можно выразить соответствующие переживания и материализовать свои субъективные мысли словами. Информация, которая передается собеседнику, является неполной, поскольку эти лингвистические сообщения являются лишь отрывком из всех идей и опыта говорящего. В психологии общения проводится различие между поверхностной и глубинной структурой языка. Глубокая структура настолько сложна, что говорящий вынужден выбирать (фильтровать) то, что он хочет сказать. То, что не попадает в этот выбор, не имеет права голоса (пространства), но все же является решающим для разговора, поскольку говорящий предполагает безымянные вещи как общую основу между собеседниками. Однако, поскольку у слушателя обычно другая модель жизни и мышления о мире, он заполнит пробелы (то есть то, что другой человек не говорит, но как предполагается совместно), а также неспецифические утверждения из своей модели мышления. Мы называем этот процесс интерпретацией.
И это происходит чаще, чем мы можем себе представить, в самом крайнем случае обе стороны говорят о совершенно разных вещах. Таким образом, характеристики уровней владения языком можно резюмировать следующим образом:

- понимание (то есть реализация речевого намерения) между партнерами по общению зависит от уровня владения языком;

- как в устном, так и в письменном общении, владение иностранным языком соответствующего партнера по общению определяет форму и содержание общения;

- различные языковые уровни, которых достигли люди, участвующие в разговоре, могут нарушить общение и вызвать недопонимание, в результате чего намерение выразить не реализуется;

- при овладении когнитивным и творческим языком цель должна заключаться в том, чтобы иметь возможность свободно общаться на изучаемом целевом языке; т.е. выбирать и использовать определенные языковые структуры в соответствии с коммуникативной ситуацией.

Человеку, изучающему иностранный язык, сложно развить и развить способность выражать себя на иностранном языке (то есть способность говорить и свободно обсуждать вопрос), особенно когда овладение иностранным языком происходит вдали от страны перевода. На уроках иностранного языка приобретаются языковые навыки и умения (аудирование, говорение, чтение, письмо) и приобретаются реальные коммуникативные языковые навыки. Говорение как основная деятельность в процессе общения является важным средством языковой реализации намерений, целей и задач партнера по общению, а также для овладения иностранным языком. Не избегая других форм разговорной речи, акцент на уроках иностранного языка делается не на знании языка, а на языковых навыках, чтобы развить способность учащегося выражать себя на иностранном языке. На основе понимания иноязычных средств дискурса происходит развитие способности к самовыражению. В соответствующей коммуникативной ситуации выражаются определенные функции речи. В процессе общения недостаточно просто знать иностранный язык и человека, с которым вы разговариваете; вы также должны обладать коммуникативной компетенцией, умением работать и правильно вести себя в ситуации (Wicke 1995, 9). Термин «коммуникативная компетенция» включает в себя взаимно сетевое мышление, социальные и межкультурные способности, языковые навыки и способность взаимодействовать с другой стороной. Коммуникативная компетенция как часть коммуникативного процесса это языковые и интеллектуальные действия субъектов, которые взаимно передают определенную информацию таким образом, чтобы другой мог ее понять. Используются как лингвистические, так и экстралингвистические средства. От переводно-грамматического метода (GÜM), 
который был введен и развит в 19 веке в обучении иностранному языку, методология иностранного языка прошла долгий путь к сегодняшнему обучению, ориентированному на учащихся, с творческими и когнитивными подходами в процессах познания. Уже в 1960-е гг. 20 века приобрел актуальность аудиоязычный метод (а также аудиовизуальный метод), поскольку основывался уже не на знании грамматики, а на устной речи. Основой новой методологии было постоянное повторение образцовых предложений и структурных моделей по принципу демонстрации и подражания. В ходе развития коммуникативной дидактики в 80-е годы прошлого века обсуждался вопрос, а где же остается на занятии по иностранному языку поведение и отношение к партнеру по общению? В процессе овладения иностранным языком вопрос развития коммуникативной компетенции учащихся стал актуальным, и с тех пор их способность выражать себя на иностранном языке стала декларируемой целью в обучении иностранному языку. Коммуникативно ориентированные уроки иностранного языка особо подчеркнули важность развития навыков аудирования, разговорной речи, чтения, письма и понимания прочитанного на слух, хотя здесь также может возникать различная весомость. (Schatz 2001, 15). Дидактические процедуры коммуникативного обучения иностранному языку также зависят от различных требований (например, от целей и намерений преподавателя, его предыдущего опыт и навыков, учебного плана и времени и т. д.). Эти рамочные условия требуют разработки и использования открытой и гибкой методологической концепции в обучении иностранным языкам. Когда разрабатывается независимая концепция дизайна уроков иностранного языка для определенной целевой группы важно следить за внутренними связями «учебного процесса». (Neuner, 1993, 128). Основываясь на специфике учебной группы и традиции обучения, учитель может разработать независимую концепцию обучения иностранному языку для соответствующей целевой группы, которая определяет общие методологические принципы:

- ориентированность на целевую группу (возраст, учебные цели и задачи учащихся, например, владение техническим языком; их знание иностранного языка);

- контентно-ориентированный (ориентация учебного процесса на актуальные интересы, соответствующего учащегося; междисциплинарное изучение иностранного языка; соответствие материала целевой группе);

- языковой функционал (устное овладение иностранным языком максимально быстро и эффективно для профессиональных или личных целей);

- межкультурный аспект (соединение языка, культуры и регионоведения; факты в целевой культуре; способность к функциональному, межкультурному общению).

Таким образом, можно выделить несколько основных положений по концептуальному дизайну коммуникативно ориентированного обучения иностранным языкам:

— преподаватель должен сформулировать цель обучения для развития разговорных и коммуникативных навыков в соответствии с соответствующими описаниями целей обучения и потребностями целевой группы;

- изучение иностранного языка должно осуществляться как сознательный и творческий процесс для достижения элементарного понимания соответствующего иностранного языка, это должно быть связано с очень конкретными профессиональными идеями обучающегося (например, как связаться с деловым партнером);

- недостаточно того, чтобы на уроках иностранного языка передавались только знания (лингвистические, культурные, региональные и т.д.), на занятии по иностранному языку должно развиваться не только знание иностранного языка (четыре навыка - аудирование, говорение, чтение, письмо), вместе с тем учащийся должен быть в состоянии применять приобретенные языковые навыки в соответствующих ситуациях;

- через ситуации изучения языка (аутентичные контексты использования) преподаватель должен спланировать уроки как неконтролируемое овладение языком, чтобы учащиеся могли сознательно относиться к формам и использованию иностранного языка, они учатся использовать иностранный язык для общения с другими партнерами по учебной группе и могут опробовать влияние языка в коммуникативных ситуациях;

- общение всегда происходит в текстовом контексте. Одновременно с развитием разговорных навыков учащиеся должны также развивать коммуникативное поведение на основе коммуникативных поводов (в процессе текста, например, данные, радиомонтаж, инструкции по применению и т.д.) в конкретных коммуникативных ситуациях;

- активизация учащегося в процессе обучения играет важную роль, в котором учащийся становится активным партнером, который поощряется к познавательному, самоанализирующему обучению и творческому отношению к иностранному языку. На занятии преподаватель должен изменить социальные формы, чтобы выполнять регулярную индивидуальную, партнерскую и групповую работу;

- на занятиях, ориентированных на учащихся, мотивация учащегося может поддерживаться в течение более длительного периода времени с помощью соответствующих стратегий (создание захватывающих ситуаций, подготовка интересных тем, импульсов, контекстов и моделей для обсуждения, введение регулярных разговорных упражнений). 


\section{ЛИТЕРАТУРА}

1. Зимняя И.А. Психологические аспекты обучения говорению на иностранном языке. М.,1979. - 159с.

2. Программа по иностранным языкам для вузов неязыковых специальностей: методические указания к программе. М.: УМ0 по лингвистическому образованию; МГЛУ // Москва, 2009. 157 с.

3. Чуднова 0.А. Устное иноязычное общение как инструмент формирования профессиональной компетентности студентов агроинженерного профиля // Успехи современной науки // 2016. Т. 1. № 7. С. 77-79.

๑ Чуднова Ольга Алексеевна (chudnova08@mail.ru), Чвалун Роза Владимировна (chvalun_roza@mail.ru), Кизилова Наталья Игоревна (natali0403_87@mail.ru).

Журнал «Современная наука: актуальные проблемы теории и практики»

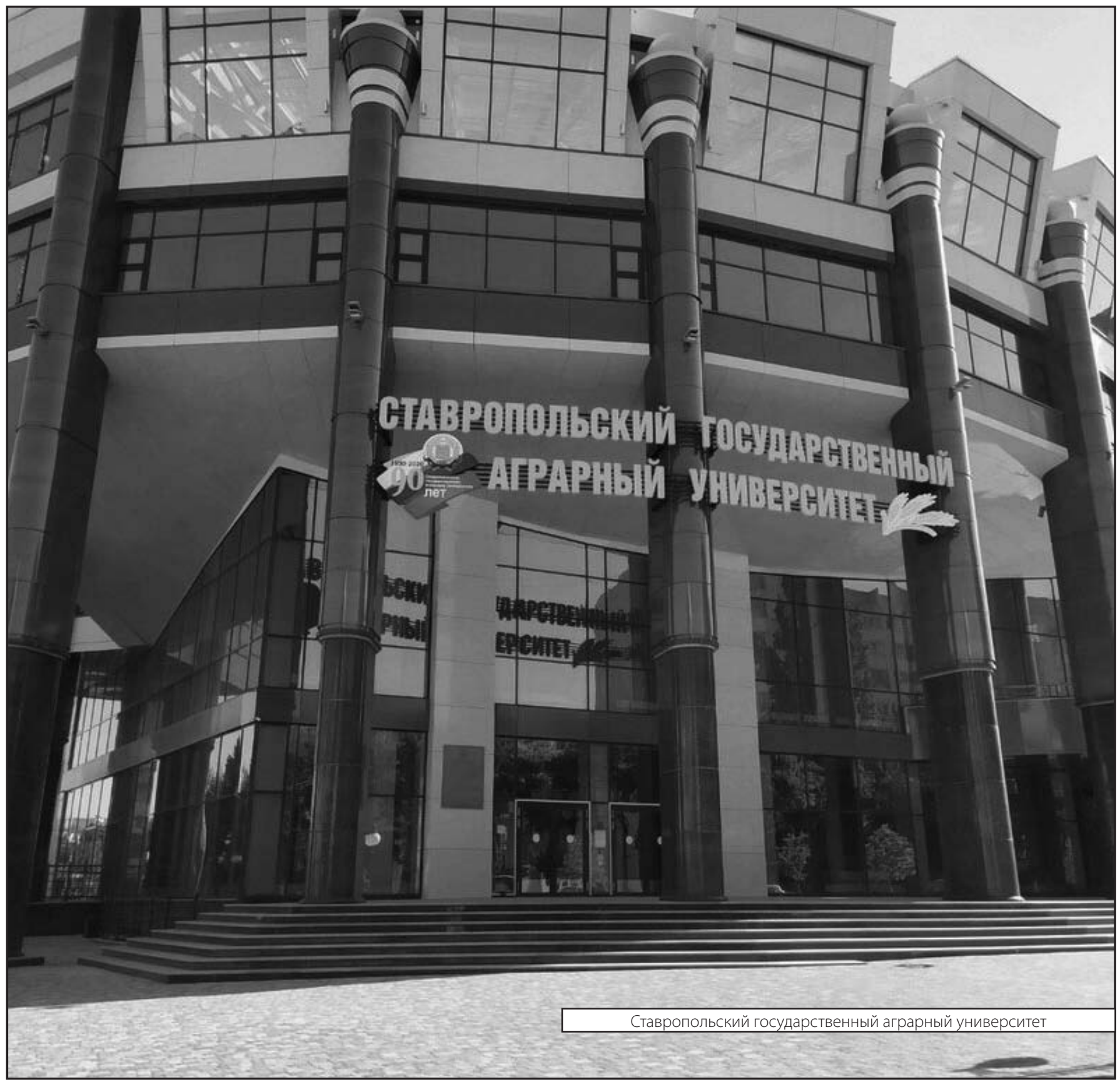

